\title{
$6 b$
}

\section{SERGIO CASALI AND FABIO STOK \\ Post-classical Commentary}

From late antiquity to the present day, a great many commentaries have been written on Virgil, and each of them gives a window onto both the reception of Virgil and the cultural features of the age in which it was produced. These two aspects can always be discerned, despite the outward continuity of the exegesis and of the tradition of materials which every commentator inherits from his predecessors. Just as the text of Virgil has been constantly reinterpreted, so too late antique commentaries have been subject to a constant process of revision, in an effort to produce an interpretation appropriate for readers at any given time: Virgil's reception is always connected to the reception of his commentaries.

In this chapter we will consider within a loose historical framework some significant moments in the history of Virgil commentaries: the transition from late antiquity to the Middle Ages, when the fifth-century commentary of Philargyrius on the Eclogues and Georgics was excerpted to produce an interpretation that would appeal to Christian sensitivities; and the 'beginning' and 'end' of the Renaissance tradition of Virgil commentaries, with the fifteenthcentury commentary of Pomponius Laetus, which could be viewed as the first modern Virgil commentary; before turning finally to Juan Luis de la Cerda, a Spanish Jesuit who, at the beginning of the seventeenth century, laid the foundations of the tradition of Virgil commentaries still alive today.

\section{Philargyrius between Late Antiquity and the Middle Ages}

Servius' commentary was not the only one written on Virgil in late antiquity. At least two others survive, those of Tiberius Claudius Donatus on the Aeneid and Philargyrius (his true name was probably 'Philagrius') on the Eclogues and the Georgics. ${ }^{\mathrm{I}}$ Whereas Servius' commentary was soon

I The name 'Philargyrius' (introduced by Politian) was suggested by the reading Filargirius / Filagirius in the manuscripts of the Explanationes, but in the Scholia Bernensia the 
adopted by the schools thanks to his grammatical approach, we do not know anything about the late antique reception of these commentaries. The origins of Tiberius Claudius Donatus are completely obscure, but he was probably a contemporary of Servius; he proposes a rhetorical reading of Virgil's poem and interprets it as praise of Aeneas and Augustus, viewing the Aeneid as an epideictic text. His commentary is clearly influenced by the declamatory tradition, which often used Virgilian themes. Tiberius sometimes argues with inherited grammatical exegeses (he does not mention any names, but Aelius Donatus is a likely target), frequently proposes moralizing interpretations, and seems to address a 'conservative' ancient reader interested in valorizing the Roman tradition. ${ }^{2}$

We are better informed about Philargyrius: in the manuscripts we read that his commentary was written at Milan during the reign of an emperor Valentinianus, identifiable with Augustus Valentinianus III (425-55 AD). According to Geymonat, Philargyrius is to be identified with Philagrius, the ancestor of the emperor Avitus who is mentioned by Sidonius Apollinaris in his panegyric (456 AD); in another poem, Sidonius mentions Philagrius' rich library (Carm. 24.93). ${ }^{3}$

Philargyrius' commentary was used by some Irish monks in the seventh century, who excerpted from it to compile two 'Expositions' on the Eclogues, followed in the manuscripts by the 'Brief exposition' on the Georgics, and the so-called 'Bern scholia' on the Eclogues and Georgics. The first 'Exposition' is signed with the name of 'Fatosus', which is the Latin version of the Irish name Toicthech. ${ }^{4}$ The Irish origin of these compilations is confirmed by the presence of glosses in old Irish. 5 The note of the first 'Exposition' on Eclogue 3.90 mentions an 'Adamnanus' who should probably be identified with Adamnán, biographer of Saint Columba and abbot of the monastery of Iona in the Hebrides from 694 to 704 . Iona was the most important centre for cultural exchange between Ireland and Britain at this time.

Besides Philargyrius, the Bern scholia also mention the names of two other commentators, Gaudentius and Titus Gallus (who seems to have commented only on the first book of the Georgics), but the core of the Irish compilations was very likely the commentary of Philargyrius. His exegetical approach differed from that of Servius. Philargyrius was not interested in grammar. He does give the meanings of rare and unusual words, but

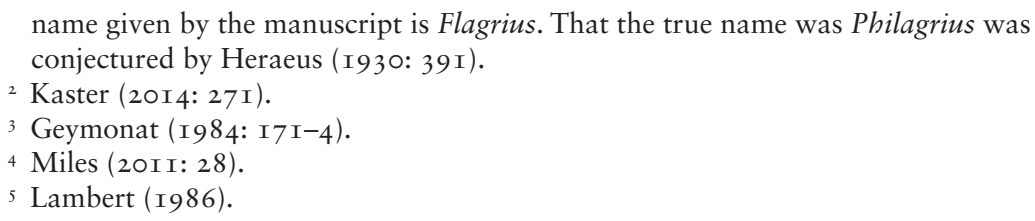


avoids the grammatical explanations frequent in Servius. He reproduces instead several interpretations of the ancient exegetes, probably using the same source used by Servius, that is the commentary of Aelius Donatus. In contrast with Servius, he often gives different interpretations, mostly in summary form but sometimes reproducing quotations from ancient authors' works (for example, Sallust's Histories). But the most striking characteristic of Philargyrius' commentary is his allegorical approach. Besides the autobiographical interpretations of the First and Ninth Eclogues, which Servius also adopts, Philargyrius records several other identifications: in the Third Eclogue Menalcas is considered a personification of Mark Antony or of Cornificius, an enemy of Virgil; in the Fifth, Menalcas and Mopsus are identified with Virgil and the poet Aemilius Macer respectively; in the Sixth, Chromis and Mnasyllus are fellow students of Virgil, and the nymph Aegle a slave of Maecenas named Leria or a friend of Varus, and so on. In the Eighth Eclogue, Moeris is presented as tutor Virgilii et magus huius rei peritissimus ('patron of Virgil and very expert in magic'), a statement that foreshadows the medieval tradition of Virgil as a magician. Philargyrius also collects anecdotes regarding problematic passages of Virgil, for example the story (also known to Servius) of a certain Caelius of Mantua who had squandered his heritage and was buried in a tomb three ells wide, the size of heaven's vault in the riddle of Damoetas in Eclogue 3.I04.

Philargyrius' commentary seems to be addressed to readers who no longer had access to the historical and literary context of the works of Virgil, but who still considered them part of their cultural heritage. Anecdotes and allegories gave Virgil's text a meaning comprehensible to these readers, together with a much-simplified digest of the over-complex and recondite exegesis collected by Aelius Donatus. Unlike Aelius Donatus, but like Servius and Tiberius Donatus, Philargyrius omits criticisms directed at Virgil's poetic choices and considers him a model of excellence. This approach seems consistent with the culture of the Gallic aristocracy we know from Sidonius Apollinaris, to which Philargyrius may have been connected. Sidonius largely imitates Virgil, but reveals a particular interest in the Eclogues and their allegorical interpretation. Sidonius was a Christian, as Philargyrius very probably was too, but there are no traces of Christianity in his works, which are informed by a classical tradition that is advanced as a model for cultural identity.

Philargyrius' commentary was recovered by the Irish compilers of the above-mentioned 'Expositions' and Bern scholia. They inserted into their compilations not only Irish glosses, but also passages from Isidore and other authors. They also knew the commentary of Servius, but considered that of Philargyrius a useful complement, which enriched their understanding of 
Virgil (the first 'Exposition' also fills the lacuna of Servius at Eclogues I.372.I9). The enlarged version of Servius' commentary, that of Servius Danielis, was very likely put together in the same context as the Irish compilations of Philargyrius. $^{6}$

Allegorical interpretations were congenial to the culture of the Irish compilers, who inserted in their compilations the Christian interpretation of the Fourth Eclogue, according to which the newborn child announced by Virgil was Jesus Christ. ${ }^{7}$ This interpretation was known already to Lactantius, but became controversial in the fourth century (it was rejected by Jerome, but accepted by Augustine). The compilers agreed on this interpretation and adopted its traditional topics, but independently from each other; the compiler of the Bern scholia is more prudent and presents some interpretations as 'our opinion' or 'according to the Christians'. The compiler of the second 'Exposition' seems more resolute and gives an allegorical interpretation of several verses of the eclogue; for example, the flores of line 23 are interpreted as the gifts of the three kings to the baby Jesus, the serpens and the herba of line 24 as the devil (diabolus) and the pagan doctrine (doctrina gentilium; the compilers usually refer to the pagans as gentiles). All compilers attribute the prophecy to the Sibyl mentioned by Virgil in line 4 and identify the virgo of line 6 (i.e. Justice) with the Virgin Mary. The compilers juxtaposed the Christian interpretation with the interpretations given by Philargyrius: the compiler of the Bern scholia writes that the progenies of 4.4 is either Saloninus or Augustus or Christ or Marcellus, son of Octavia, simply adding the Christian reading to the traditional ones. In other cases, the compiler modifies the ancient exegesis and inserts his own observations. The note of the Bern scholia to Georgics 4.493 is attributed to Gaudentius, but in fact it seems partly attributable to the compiler himself, who says that Orpheus descended into hell (descendit in infernum), but who also observes at the end that the whole story of Orpheus and Eurydice is a falsehood invented by the pagans (ridiculosa gentilitas fingit falsa).

The compiler of the first 'Exposition' completed his commentary on the Eclogues with a biography of Virgil largely reproducing that of Donatus, with some omissions and some modifications which moralize Donatus' references to Virgil's sexual life. ${ }^{8}$ This attempt at moralization also appears in the commentary, with regard to the traditional identification of Alexis with a boy given to Virgil by Asinius Pollio. In notes on Eclogue 2.I, the compiler of the first 'Exposition' writes that Virgil loved boys, but not

\footnotetext{
${ }^{6}$ Stok (20I 5a: 296-7).

7 Stok (20I8).

${ }^{8}$ Stok (2OI4-I 5$)$.

98
} 
'shamefully' (turpiter), whereas the compiler of the second takes into consideration the possibility that Alexis was Augustus himself or a slave boy of Augustus, and that Virgil praised him to eulogize the emperor.

The compilations based on Philargyrius' commentary enjoyed a little success in the eighth and ninth centuries, after which they were eclipsed by Servius' commentary.

\section{Pomponius Laetus' Ghost Commentary}

Servius' commentary was obscured in the late Middle Ages by new commentaries which reflected the demands of 'modernity' which arose in the twelfth century. An influential revision of Servius' commentary was written by Hilarius of Orléans, a teacher in Angers between II05 and II23; his commentary (formerly attributed to Anselm of Laon) omits parts of the quotations and many of the grammatical exegeses provided by Servius, but adds historical and rhetorical notes, explains words whose meaning had changed during the Middle Ages, and sometimes incorporates from Eusebius episodes from biblical history (for example, in a note on Aeneid I.265 the fall of Troy is situated at the time of Moses' flight from Egypt). A commentary on the first six books of the Aeneid is attributed to Bernardus Silvestris (twelfth century); it renews the allegorical approach introduced in late antiquity by Fulgentius (fifth-sixth century), and interprets the plot of the Aeneid as an integumentum ('covering') of philosophical truths. This commentary was influenced by the Platonism of the school of Chartres. Zono de' Magnalis, a master in Montepulciano near Siena in the first decades of the fourteenth century, wrote an ample commentary on the whole of Virgil in which he collected several literary and historical sources available in his time; at times he adopts an allegorical approach; he also endorses the authenticity of the Helen episode. The English Dominican Nicholas Trevet (I265-I335) commented on the Eclogues in the light of contemporary Aristotelianism.

It was the humanists who rediscovered Servius' commentary. The forerunner of this revaluation of Servius was Petrarch (I304-74), who read Virgil together with Servius in his famous codex illuminated by Simone Martini (now in Milan, Biblioteca Ambrosiana S.P. IO, 27). The popularity of Servius in the fifteenth century is revealed by the large number of manuscripts and by the interest devoted to him by Guarino of Verona and his school. Other humanists, such as Lorenzo Valla, were more critical of Servius, and so Pomponius Laetus, successor of Valla at the Studium of Rome, prepared a new commentary for the courses he held on Virgil from I47I. 
Following the printing of the editio princeps of Virgil, without any commentary, at Rome in I469, between I469 and I 599 around I 50 separate commentaries on Virgil, by at least I 25 different authors, were produced. Some of them would appear in thirty or more editions. ${ }^{9}$ Pomponius Laetus, however, did not publish his commentary, even though he collaborated from I 470 with printers active in Rome, but it survives in manuscript. The reasons for his choice are not clear. In a letter written to Agostino Maffei in I490, Laetus affirms that in order to interpret Virgil it was necessary to know his world (cognitio rerum), and that he was conscious of his own ignorance on this point. ${ }^{\mathrm{IO}}$ This statement is consistent with the whole approach of his commentary, which aims to illuminate the cultural and historical dimensions of Virgil's world, but it does not fully explain Laetus' resolution not to publish his commentary in a printed edition. His behaviour seems somehow consistent with the esoteric aspects of the Roman Academy he founded, whose members sometimes convened in the catacombs of Rome. Laetus made two important discoveries around I470, thanks to his relationship with the monastery of Bobbio, which he shared only with his pupils: the late antique Mediceus manuscript of Virgil (now in Florence, Biblioteca Laurenziana Plut. 39.I) and the commentary on the Eclogues and Georgics attributed to Valerius Probus. Both discoveries were long known only to Laetus' circle, and were not publicized until the sixteenth century.

Around I 490 a manuscript of Laetus' commentary was used by a printer based in Brescia to publish a pirated edition; it is not known how the editor, Daniele Gaetani, came into possession of it. Laetus promptly disavowed it, in the same letter to Maffei. Nevertheless the commentary was later reprinted by Johannes Oporinus (I 544) and by Georg Fabricius (in his several editions of Virgil from I 56I) under the name 'Pomponius Sabinus'. Commentators until Heyne used it and frequently mentioned this name, and it was not until I 824 that Naecke established that the mysterious Pomponius Sabinus was indeed Pomponius Laetus. ${ }^{\text {I }}$

The original version of Laetus' commentary, transmitted by some manuscripts, remains unpublished. It concerns not only Virgil's works, but also the Appendix (indeed the first printed commentary on the Appendix, published in $\mathrm{I} 480$ by Domizio Calderini, largely plagiarized that of Pomponius). Despite some ambiguities and idiosyncrasies, Laetus' commentary can be considered the first Virgilian commentary of the modern age.

\footnotetext{
9 Wilson-Okamura (2010: 24-3I).

то The letter was published in Laetus' edition of Sallust printed in Rome, also in I 490 .

II Naecke (I 842: I I9-43). 
Laetus had historical and antiquarian interests (he collected inscriptions and other archaeological items). Several of his notes on Virgil deal with religion and ritual, customs, and geography, among other topics, and include explanatory quotations from Pliny the Elder, Livy, Dionysius of Halicarnassus, Theophrastus, and many other Greek and Latin authors. Laetus also frequently identifies Virgilian parallels in Lucan, Silius, and Statius' Silvae, works which either Laetus or students of his school had commented on in previous years.

In several cases Laetus corrects or improves on the exegesis of Servius. ${ }^{\mathrm{I2}}$ At Aeneid 7.563, Virgil presents the Valley of Amsanctus, through which Allecto returns to the Underworld, as a 'place in the heart of Italy' (locus Italiae medio). Servius, following Aelius Donatus, criticizes medio on the grounds that Amsanctus is in Lucania in southern Italy. Laetus redeems Virgil's medio, pointing out that Virgil's geographic indications refer to preRoman Italy, and quotes Pliny, who writes that the Rubicon was the ancient frontier of Italy ( $\mathrm{NH}_{3}$. I I 5 ).

Commenting on the Eclogues, Laetus adopts a strongly autobiographical reading. He did not know Philargyrius' commentary, but mainly used that of pseudo-Probus. The same approach is adopted in regard to the Culex and the Dirae, which he obviously attributed to Virgil. The allegorical reading allowed Laetus to write an innovative Life of Virgil, which he probably used as an introduction to his lectures on the poet. ${ }^{\mathrm{I}} \mathrm{In}$ it he highlights some aspects of the biographical tradition previously censored, such as Virgil's sex life and his Epicurean sympathies. These sections may also partly explain Laetus' cautious stance on publishing his commentary; after all, in I468 he had been imprisoned and accused of heresy, paganism and homosexuality.

Laetus frequently adopts the textual variants he found in the codex Mediceus, against the vulgate text printed in the I47I Roman edition by Sweynheym and Pannartz. For example, at Aeneid 4.27 Laetus read in the Mediceus the correct violo ... resolvo, as against the vulgate violem ... resolvam. In some cases he also includes in the textual discussion the variant given by the commentary he attributed to Probus. At Aeneid 2.69I he prefers Probus' augurium to the auxilium read by the Mediceus. Sometimes Laetus himself offers conjectures, as in the case of Aeneid I.2, where the textual alternative Lavinaque/Laviniaque was known to Servius, who preferred Lavinaque. Laetus read Lavinaque in the Mediceus but conjectured Lavinia (and wrote this correction in the Mediceus itself!).

\footnotetext{
I2 Stok (2OII).

I3 Stok (2015b).
} 
In several cases Laetus attributes the variants of the Mediceus to 'Apronianus', shorthand for Flavius Turcius Rufius Apronianus Asterius, a Roman aristocrat and consul in 494, whose name appears in the subscript of the manuscript. Laetus is rather ambiguous about this figure, and sometimes presents Apronianus as an ancient commentator. One of the good variants recovered by Laetus from the Mediceus is tenet at Aeneid 7.4I2 et nunc magnum tenet Ardea nomen ('and Ardea still retains a mighty name') - as against the vulgate's manet: Laetus presents the variant as read by Apronianus (Apronianus legit), and elsewhere attributes to Apronianus not only a reading, but also exegetical comment. Scholars long thought that the mysterious Pomponius Sabinus knew a lost commentary written by Apronianus. This belief was a by-product of the complicated history of Laetus' commentary.

\section{La Cerda and the Foundation of the Modern Commentary Tradition}

In the bibliographies of the late twentieth- and twenty-first-century commentaries on Virgil, neither Pomponius Laetus nor any of the multitude of Virgil commentaries published in the fifteenth and sixteenth century are considered. In the history of the modern Virgilian commentary tradition we register a strong rupture at the end of the eighteenth century with the commentary of Christian Gottlob Heyne (I729-I 8 I2), whose first edition appeared in four volumes between I767 and I775. ${ }^{\mathrm{I}}$ Only one pre-Heyne commentary survives in the bibliographies of the most recent commentaries on Virgil: the three-volume commentary of the Spanish Jesuit Juan Luis de la Cerda (c. I 558-I643), published in I608 (Eclogues and Georgics), I6I2 (Aeneid I-6), and I6I7 (Aeneid 7-I2). This survival is not a matter of chance: there are qualitative and quantitative differences between La Cerda and his predecessors. Not only is his work considerably longer than any of the other early modern Virgil commentaries, but La Cerda is also an immensely erudite scholar (note the enormous number of parallels from ancient authors both earlier and later than Virgil) who exhibits an acute sensitivity for the interpretation of Virgil's works. If it is true that we are living in a 'neo-baroque' age, his typically baroque sensitivity may paradoxically make him in some ways a more 'modern' commentator than not only his Renaissance predecessors, but also many of his now more commonly consulted successors, and in fact some of his notes are more likely to be

\footnotetext{
${ }^{14}$ Heyne (I 767-75); most commonly used today is Heyne and Wagner (I 830-4I). 
appreciated in the present day than in the past. ${ }^{\mathrm{Is}}$ For example, less than a century after the publication of La Cerda's commentary, the Italian priest and author Ludovico Antonio Muratori could reject as nonsense La Cerda's observation that at Aeneid 10.834, where Mezentius vulnera siccabat lymphis (lit. 'dried with water his wound'), Virgil intended to create an 'acumen', that is a 'witticism'. ${ }^{16}$ Of course, today we have no problem seeing 'an apparent oxymoron'. ${ }^{17}$ To take another example, Conington defines as 'of course absurd' La Cerda's suggestion that at Aeneid 4.27 I aut qua spe Libycis teris otia terris? ('or what are you hoping to do by idling your time away in the Lybian lands?'), the cluster teris ... terris alludes to the ancient etymology of terra from tero. ${ }^{18}$ On the contrary, for O'Hara there can be no doubt that this really is the case, and Muse goes so far as to see in the wordplay teris ... terris an imitation of the similarly etymological Homeric wordplay at Odyssey I 5.IO involving the Tel- ('far') in Telemachus. ${ }^{19}$

La Cerda spent most of his adult life teaching students in a Jesuit preuniversity school, the Colegio Imperial of Madrid, as a professor and a 'prefect of studies', and the didactic aims of his commentary are evident and pervasive.${ }^{\circ} \mathrm{La}$ Cerda's commentary is didactic in two ways: he wants both to explain Virgil, and to teach his students how to compose poetry. In his address to the reader at the beginning of the first volume, La Cerda explains that he divided his work into Argumenta, that is brief statements of the subject of the chunk of text under consideration; Explicationes, that is explanatory paraphrases which often contain the main interpretative points and explain 'the mind of Virgil'; and Notae, more minute miscellaneous observations by which he proposes to confirm the explanation given in the Explanatio, to expound - but only rarely - the opinions of others, and to collect parallels from Greek and Latin authors both preceding and following Virgil. The stated aim of this massive accumulation of parallels is to teach how properly to compose poetry by observing the ways in which Virgil imitated his Greek predecessors, and also the ways in which his followers imitated him - almost always unsuccessfully, it will turn out - but in such

I5 On La Cerda’s 'baroque' approach to Virgil, see Mazzocchi (I993: 663-6); Casali (2008). On postmodernity as a neo-baroque age, see the seminal Calabrese (I992); and Lambert (2004); Ndalianis (2004); Egginton (2010).

${ }^{16}$ Muratori (I706: ii.554), quoted by Mazzocchi (I993: 663).

17 Harrison (I991: ad loc.).

${ }^{18}$ Conington (I 872: ad loc.). Cf. Varr. LL 5.2I (attributing it to Aelius Stilo fr. 39 GRF); Isid. Orig. I4.I.I.

19 O'Hara (2017: I 55 ); Muse (2005).

20 The starting point on La Cerda's life is still Simón-Díaz (I944); cf. (I992: 52 I-2). See also, with due caution, Stevens (I945: 20I-I7). A brief summary and further references are provided by J. Escalera in O'Neill and Domínguez (200I: I.734). 
a way as to work as a stimulus for the students in their own practice of imitation.

La Cerda is notably reticent in his Foreword regarding the names of his predecessors. He only mentions 'Germanus Valens Guellius P. P.' (i.e. Pimpontius), Germain Vaillant de Guélis ( 15 I 6-87), Abbot of Paimpont and Bishop of Orléans from I 585 to his death, as the one whose judgement he considers the most authoritative. ${ }^{21}$ In the course of La Cerda's commentary, indeed, Germanus (I 575 ) is the most frequently cited of the preceding commentators of Virgil, if perhaps not the most cited name, an honour probably to be split between Julius Caesar Scaliger and his son Joseph Justus - neither of whom, however, had written a proper Virgilian commentary (apart from Joseph's commentary on the Appendix (I573), also printed at the end of the commentary of Germanus). Germanus' commentary was much more concise than that of La Cerda, but what most attracted La Cerda's attention was probably the space it devoted to Virgil's Greek models, starting of course with Homer and Apollonius. Germanus had been preceded in this especially by the I 567 'monograph' of Ursinus (Fulvio Orsini, I 529-I600) specifically dedicated to Virgil's Greek models, published by Plantin of Antwerp, and in fact Germanus' detractors accused him of having plagiarized Ursinus. ${ }^{22}$

Germanus, the only commentator mentioned in the epistle to the reader, is but one of I 50 names of modern scholars listed in the 'syllabus' which forms part of the prefatory materials of La Cerda's first volume. Not all of these names belong to scholars of Virgil and, more importantly, not all the Virgilian commentators and interpreters cited in the course of the commentary are present in this list. For example, Jodocus Badius Ascensius, the most frequently printed of the early modern commentators on Virgil, is absent from the syllabus, and is in fact very rarely quoted in the notes; Ascensius' annotations are evidently too elementary to merit La Cerda's attention. ${ }^{23}$ To take another example, also absent from the syllabus is another commentator whom instead La Cerda quotes often enough and usually with approbation, Nascimbene Nascimbeni, author of a commentary on the first six books of the Aeneid (I 577), which was often used, notwithstanding Nascimbeni's heretical tendencies, ${ }^{24}$ by the other major Jesuit commentator of this period,

${ }_{21}$ On Germanus' life and works, see Delacourcelle (I954).

22 Delacourcelle (1954: 354). On the history of early modern Virgil commentaries in light of their preoccupation with Greek models and Homer in particular, see Knauer (I964a: 3I-I06).

${ }_{23}$ On Badius Ascensius, also a famous printer, as a scholar and commentator, see the fundamental study of White (20I3: 6I-I06 and 207-33).

${ }^{24} \mathrm{He}$ was persecuted by the Inquisition for his involvement with the cult of Giorgio Siculo. See Prosperi (2000: 322-40). 
Jacobus Pontanus (Jakob Spanmüller, c. I 542-I626), whose work appeared in 1599.25

In fact, from a 'moralistic' point of view, both Pontanus and La Cerda appear relatively uninhibited. For example, they both ignore the prescriptions of the Ratio studiorum ('Plan of studies') adopted in I 599 by the Society of Jesus regarding the prohibition on reading some of the Eclogues and Book 4 of the Aeneid at school. According to the Ratio, during the penultimate class of the lower curriculum, 'Humanities', mainly dedicated to poetry, and propaideutic to the final class, 'Rhetoric', the students should have improved their style and obtained 'correctness of expression and ample vocabulary' through daily readings of Cicero's moral works, of the historians, and, with respect to poetry, of Virgil, 'with the exception of some eclogues and the fourth book of the Aeneid' (plus selected odes of Horace, to which might be added 'elegies, epigrams, and other poems of recognized poets, provided that they are purged of all immoral expressions'). ${ }^{26}$ Not only does La Cerda not flinch in the face of Eclogues such as the second one, but sometimes he is less prudish than some of his twentieth-century successors. For example, when at Aeneid 4.3 I7-I 8 Dido begs Aeneas to reconsider his decision to leave Carthage, si bene quid de te merui, fuit aut tibi quicquam I dulce meum ('if ever I deserved well of you, or if anything of mine has been sweet to you'), the sexual reference in the second half of this clause worried interpreters even before Servius' time. Servius, for his part, clearly saw that Dido tegit rem inhonestam ('covers up a shameful thing') - quoting Terence's Andria 294: seu tibi morigera fuit in rebus omnibus ('if she has been complying with you in all things') - but Servius Danielis reports that other interpreters were uncomfortable with this explanation, and advanced various ways to neutralize Dido's reference to res veneria ('intercourse'). Just such an attitude can still be found in the great 1935 commentary on Aeneid 4 of A. S. Pease: 'We need not, with Servius ..., take this clause in an obscene sense ...; cases of dulce so employed, collected by various editors, are not adequate to prove a bad sense here', and this after having accumulated parallels from Greek poetry (especially Pind. Olympians I.75-6 and Sophocles Ajax 520I) that prove beyond any doubt that a 'bad sense' is just what is meant here. In his 'explicatio', La Cerda (who, by the way, already had access to Servius Danielis) knows how to say the needful without compromise: velat modestissime rem coningum, tantum indicata voluptate ('she most modestly veils the conjugal intercourse, mentioning only the pleasure of it'); in his note, he further clarifies: dulce] Pindarus Od. I Olymp. [Ol. I.75] qí $\lambda_{l \alpha}$

${ }_{25}$ On Pontanus see, most recently, Leinsle (2009); Rädle (2013: 266-8).

${ }_{26}$ Trans. Farrell (I970: 80). 


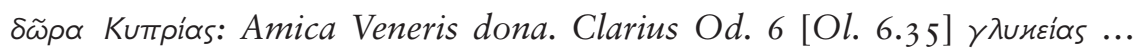
'Appoditas: Dulcis Veneris ('Pind. Ol. I.75 "Venus' pleasing gifts". More clearly at $\mathrm{Ol}$. 6.35 "of sweet Venus"'). ${ }^{27}$ For his part, La Cerda's fellow Jesuit Pontanus ('our Pontanus', as La Cerda usually calls him) also candidly reprised Servius' note without softening its content. In fact, far from disliking Dido, La Cerda goes so far as to declare her reaction to Aeneas' farewell in the Underworld to be the part of the Aeneid in which Virgil is at his absolute best; in the 'explicatio' to Aeneid 6.467-76, he says that Totus hic locus, ut vivide intelligatur, pendet ab his, quae dicta 4. Aen. Cum enim magnus ubique Poëta, tum maximus in hac vicissitudine Didonis, et Aeneae ('all this passage, in order for it to be understood in its full vividness, depends on what was said in Book 4. For, although Virgil is a great poet at every point, in no place is he greater than in this exchange of roles between Dido and Aeneas'). He then proceeds to an analysis of the passage that shows how in the Underworld Aeneas and Dido have exchanged the roles they played in Book 4: 'a profound, double reversal of roles' is Horsfall's comment ad loc. ${ }^{28}$ where he cites seven items of bibliography on the subject, the oldest being Cartault. ${ }^{29}$ It is fascinating to note how all these 'modern' observations are already contained in nuce in La Cerda, and even more fascinating to realize that La Cerda was not the first to notice that reversal of roles. He does not cite any predecessor on this occasion, but Pontanus, on Aeneid 6.47 I (quam si dura silex ...), reproduces (something La Cerda never does, always reworking in his own words the notes of his predecessors) the note of Nascimbeni, who observed how Virgil, by comparing Dido to an immovable rock:

egregie sane duram Didonem, atque animo immobilem duritiae, immobilitatique animi Aeneae ex aequo respondere facit: nam ut Aeneas nullis Elisae fletibus movetur in quarto, ita hoc in loco vicissim Elisa Aenea lacrymante, atque etiam orante nihilo melius movetur. quamobrem et Aeneam quercui, cum ait: Et veluti annosam ... quercum ... et Didonem hic silici comparavit.

well does he make Dido, hard and immovable in her mind, correspond exactly to the hardness and immovableness of Aeneas; for just as Aeneas is not moved by any weeping of Dido in Book 4, so here in her turn Dido, while Aeneas

\footnotetext{
27 The reference to Pind. Ol. I.75-6, actually more to the point than that to Ol. 6.35, goes back at least to Ursinus ( $1567: 286-7$ ), who also quotes the highly relevant words of Tecmessa at Soph. Ai. 520-I. On the philological reception of Aen. 4.3 I7-I 8, see Finglass (2020).

${ }^{28}$ Horsfall (2013: 343).

29 Cartault (I926: 1.456-7).
} 
cries and even begs, is not moved more than he was. For this reason, Virgil has compared both Aeneas to an oak, when he said 'and like an old oak' ... and Dido here to a rock.

Early modern Virgil commentaries are interesting not only from a strictly historical perspective, but also for what they can still contribute to a proper understanding of the text.

\section{FURTHER READING}

On Tiberius Donatus, see Starr (I992); on Philargyrius, see Funaioli (I930); the 'Explanations' and the Bern scholia are in Hagen (I902) and (I 867); for a recent edition of the commentary on G. I.I-42 see Cadili (2003). The commentary attributed to Bernardus Silvestris is published in Jones and Jones (I977), that of Nicholas Trevet in Nascimento and Díaz de Bustamente (I984); the commentaries of Hilarius of Orléans and Zono de' Magnalis are unpublished; on the attribution to Hilarius, see De Angelis (I997); on Hilarius' commentary on the Aeneid, see Bognini (2005), and on Zono, Stok (I99I). On Pomponius Laetus' commentary, see: Lunelli (20I4), Stok (2009, 20I4).

Scholarship on both classical commentaries in general and Renaissance and early modern commentaries is increasingly flourishing. Interesting collections of essays on the traditions of the commentary on classical authors are Gibson and Kraus (2002) and Kraus and Stray (2016); for Renaissance neo-Latin commentaries specifically, see Enenkel and Hellen (2013) and Enenkel (2OI4). For a survey of the practices of commentary from antiquity to the present, see Grafton (20I0). See also Copeland and Sluiter (20I2) and Zetzel (20I8).

The scholarly reception of Virgil in the Renaissance has been explored by Craig Kallendorf in a series of fundamental studies; see most recently, Kallendorf (2OI5) and his essential bibliography of all the early printed editions of Virgil (including commentaries) (20I2). Wilson-Okamura (2010) gives ample space to commentaries up to I 599; his Appendix B lists the commentaries on Virgil according to the number of editions that contain them. For a brief useful survey of the history of Virgil commentaries from ancient to modern times see the multi-authored 'commentaries' entry in Thomas and Ziolkowski (2014: 288-95).

On La Cerda's commentary see also Laird (2002). On the growth and spread of Jesuit schools, initially not a fundamental part of Ignatius' project but soon destined to become a major source of glory for the Society, with over 800 schools open worldwide by the time of the Suppression (I773), see 
O’Malley (I993: 200-42). On Jesuit humanism, pedagogy, and education there is a vast bibliography: the classic study is Codina Mir (I968); more recently see Casalini and Pavur (20I6). On the Jesuits' attitude to Virgil, especially from the point of view of the theorists and practitioners of imitation, see the excellent studies of Haskell (2OIO) and (20I4). 